\title{
Effects of Fermented Sumach on the Formation of Slime Layer of Staphylococcus aureus
}

\author{
Sahra Kırmusaoğlu', Seyhun Yurdugül', Esra Koçoğlu² \\ ${ }^{1}$ Department of Biology, Faculty of Sciences, Abant izzet Baysal University, Bolu, Turkey \\ ${ }^{2}$ Department of Microbiology, Izzet Baysal Faculty of Medicine Research and Education Hospital, Abant Izzet Baysal University, Bolu, Turkey
}

\begin{abstract}
Objective: Staphylococcus aureus (S. aureus) is one of the most commonly isolated bacterial pathogens in hospitals, and the most frequent cause of nosocomial infections. Nosocomial staphylococcal foreign-body infections related to biofilm formation are a serious threat, demanding new therapeutic and preventive strategies. Implantation of intravenous catheters and surgical implantation of prosthetic implants carry a risk of infection. In order to prevent all these effects of biofilms, a study was designed to observe the possible antibacterial effect of sumach (Rhus coriaria) on the biofilm formation of S. aureus.
\end{abstract}

Material and Methods: The influence of varying concentrations of sumach on the formation of biofilms by 13 strains of Staphylococcus aureus was tested by a microelisa assay.

Results: The significant differences between varying concentrations of sumach $(0.1,0.2,0.5$ and $1.0 \mu \mathrm{l} / \mathrm{ml})$ were observed in four methicillin resistant Staphylococcus aureus (MRSA) and nine methicillin sensitive Staphylococcus aureus (MSSA) $(p<0.05)$. In bacteria, a dose-related decrease in the formation of slime, which is a major virulence factor of staphylococcal infections, was observed.

Conclusion: In our study, using $0.1,0.2,0.5$ and $1.0 \mu \mathrm{l} / \mathrm{ml}$ of sumach, thirteen strains lost, $17 \%, 22 \%, 28 \%$ and $48 \%$ respectively of their capacity to produce biofilms. Sumach, which is a herbal product, can decrease the formation of biofilm, which is a major virulence factor in staphylococcal infections.

Key Words: Staphylococcus aureus, biofilm formation, Rhus coriaria, Indwelling device-associated infections

Received: 27.01.2011 Accepted: 25.05.2011

\section{Introduction}

The increasing numbers of multidrug-resistant Grampositive pathogens have generated worldwide concern in the medical community. The emergence and spread of the methicilin resistant S.aureus (MRSA) has been shown to be associated with both hospital- and community-acquired infections. Effective treatment options for these infections are limited and the situation may soon become more severe. For these reasons, a proactive management of MRSA in healthcare facilities is needed $(1,2)$. The use of different types of antibiotics over the years has led to the emergence of multi-resistant MRSA strains (3). Although the types and severity of diseases produced by the opportunistic pathogen, S.aureus, vary, it was reported to be a frequent cause of infections associated with indwelling medical devices (e.g., catheters and artificial heart valves) (4).

In a biofilm, bacteria are well protected from the host immune defense. An increase in antibiotic resistance is the consequence (5-7) and even high local concentrations of antibiotics do not completely eradicate bacteria in biofilms $(6,8)$.
The increasing occurrence, particularly in hospitals, of $S$. aureus resistance including to methicillin and a wide range of antimicrobial agents like all kinds of $\beta$-lactams, has made therapy more difficult (9-12). Although strategies have been proposed in an attempt to control the spread, the search for new ways to treat MRSA infections stimulates the investigation of natural compounds as an alternative treatment of these infections (13).

Indwelling device-associated infections commonly involve the formation of a bacterial biofilm on an uncoated plastic surface or on a plastic surface coated with host proteins (4).

Rhus coriaria (Sumach) and some other species of Rhus powdered leaves and fruits which have antibacterial properties have also been reported by other researchers $(14,15)$. Sumach is rich in water-soluble tannins, and the antimicrobial activity of tannins is well documented (16). Nasar-Abbas and Halkman (2004) have demonstrated that not only the organic acids but also the other substances in water-extracted sumach were found to be effective antimicrobial agents (17). It is generally believed that the fully protonated species of organic acids can diffuse into the bacterial cells, and cause cell death (18-20). The fermented sumach is widely used as a salad dressing in the South Eastern provinces of Turkey. 


\section{Material and Methods}

The Bacteria: Thirteen S. aureus isolates which had been recruited from the samples of patients who visited the microbiology laboratory of the hospital of Abant Izzet Baysal University, Faculty of Medicine, Bolu, Turkey. Four of these strains which were found to be methicillin resistant Staphylococcus aureus (MRSA) and nine of them reported as methicillin sensitive Staphylococcus aureus (MSSA), in a previous study were inoculated into the blood agar and grown at $37^{\circ} \mathrm{C}$ for a period of 24 hours. The relevant isolates were treated with the fermented sumach, which was put in the tryptic soy broth (TSB) (Merck ${ }^{\mathrm{TM}}$ ) for 24 hours and $37^{\circ} \mathrm{C}$ in an incubator in contrst to the controls of the isolates, which were studied in nonfermented sumach added TSB for 24 hours and $37^{\circ} \mathrm{C}$ in an incubator.

The Fermented Sumach: The fermented sumach was obtained from a local vendor in Gaziantep, Turkey. It was prepared by grinding with up to $20 \%$ salt and left for fermentation.

The Experimentation: The treatment including four different concentrations of the fermented sumach were added to each microtiter plate in the microelisa reader instrument (Thermo Instruments ${ }^{\mathrm{TM}}$ ), containing TSB and analyzed separately. The concentrations of the fermented sumach were 0.1 , $0.2,0.5$ and $1 \mu \mathrm{l} / \mathrm{mL}$. In all the microtiter plates, TSB was used and the process was repeated in triplicate. The isolates were inoculated to cuvettes (LP Italiana SPA ${ }^{\mathrm{TM}}$ ) which contained the treated and non-treated groups.

\section{The Qualitative Determination of Slime}

(i) Congo red Agar method (CRA): In order to screen out the biofilm formation by $S$. aureus, the bacteria were grown on Congo red agar (Merck ${ }^{\mathrm{TM}}$ ) as described by Freeman et al. (1989) (21). The colony morphology was examined after $24 \mathrm{~h}$ at $37^{\circ} \mathrm{C}$. A positive result was indicated by black colonies.

(ii) Tube method: The case study was verified by an assay, in which the biofilm formation by bacteria was additionally detected by another method described by Christensen et al. (22) by overnight cultivation of $S$. aureus, inoculated in polystyrene test tube which contained TSB as an alternative. The biofilms formed on the walls of the polystyrene test tube were washed twice with phosphate-buffered saline (PBS) to remove the planktonic cells. Then, the cells were stained with saphranin for 1 hour. After discarding saphranin, the polystyrene test tube was washed twice with PBS, followed by the air drying of the polystyrene test tube. Slime production was judged to have occurred if a visible film lined the walls of the tube (22). The adherent bacterial films were measured spectrophotometrically at $540 \mathrm{~nm}$ in a microplate reader (Thermo Instruments $\left.^{\mathrm{TM}}\right)$. This process was repeated with $0.1,0.2,0.5$ and 1 $\mu \mathrm{l} / \mathrm{mL}$ concentrations of sumach treated TSB to determine the effects of sumach on slime production of isolates. The studies were repeated in triplicate.

\section{The Quantitative Determination of Slime}

(i) Spectrophotometric method: The different concentrations of sumach were mixed with TSB and non-treated TSB were used for controls. The optical density (OD) value of the inoculum was adjusted to approximately 0.600 by a spectro- photometer (Hitachi ${ }^{\mathrm{TM}}$ ). $200 \mu \mathrm{l}$ of bacterial suspension were inoculated into 96-well flat-bottomed sterile polystyrene microplates (LP Italiana SPA ${ }^{\mathrm{TM}}$ ) which contained TSB. Some wells were left free of fermented sumach as controls and incubated for $24 \mathrm{~h}$ at $37^{\circ} \mathrm{C}$. The biofilms formed on the plates were washed twice with phosphate-buffered saline (PBS) to remove the planktonic cells. Then, the cells were stained with saphranin for 1 hour. After discarding saphranin, the microplate was washed twice with PBS, followed by the air drying of the wells. The adherent bacterial films were measured spectrophotometrically at $540 \mathrm{~nm}$ in a microplate reader (Thermo Instruments $^{\mathrm{TM}}$ ). This process was repeated with $0.1,0.2,0.5$ and 1 $\mu \mathrm{l} / \mathrm{mL}$ concentrations of sumach treated TSB to determine the effects of sumach on slime production of isolates. The studies were repeated in triplicates.

The Determination of the Slime Index (SI): Following a period of 24 hours incubation of isolates which are treated with the different concentrations of the fermented sumach, the growths of $S$. aureus were confirmed with the microelisa reader instrument (Thermo Instruments ${ }^{\mathrm{TM}}$ ). The O.D. value of the biofilm corresponded to the value in O.D. of bacterial growth determined spectrophotometrically, before the aspiration of the culture in order to compensate the partial inhibition in growth caused by the fermented sumach and this was termed as the slime index (SI). The result was expressed as a percentage relative to the control without fermented sumach. For this purpose, the following formula was applied: $\mathrm{SI}=100 \mathrm{x}$ (mean density of biofilm with supplement/mean growth with treatment)/(mean density of biofilm without treatment/mean growth without treatment) (Pérez-Giraldo C. et al., 1997) (23).

\section{Statistical analysis}

The Friedman test was used to detect the existence of differences in growth and biofilm formation among the different groups. The significance level was set for $p<0.05$ in the evaluation of Friedman test results. Where significant differences existed, comparison between the concentrations of sumach was carried out by the two related sample test (Wilcoxon test). The Bonferroni correction was made in the evaluation of $p$ values which were obtained from the Wilcoxon test. The significant level was set for $p<0.017$ in the evaluation of Wilcoxon test results.

\section{Result}

The 13 strains of $S$. aureus included in this study were found to be biofilm-producing. Strains which were not treated with sumach produced a slime layer of which O.D. value ranged from 0.074 to 0.389 . A total of 13 strains gave an O.D. of $>0.100$. Strains which were treated with sumach had a decreased biofilm with an O.D. value ranging from 0.082 to 0.070 . The results of growth and biofilm formation in the presence of different concentrations of sumach determined by spectrophotometrical assays are presented in the Table 1.

It was found that there were significant differences in growth between the concentrations of 0.1 and $1.0 \mu \mathrm{l} / \mathrm{ml}$ (Table 2). In addition, there were significant differences in biofilm formation of MSSA and MRSA between concentrations of sumach. Probably the decrease in the O.D. of the biofilms was 
Table 1. The Friedman test results which show the effects of different concentrations of sumach on the growth and biofilm formation of 13 isolates

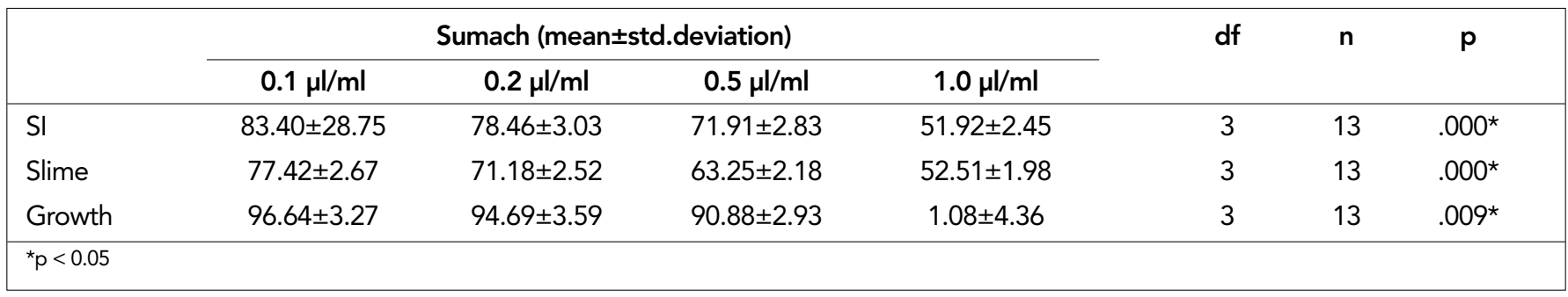

Table 2. The wilcoxon test results which show the effects of different concentrations of sumach on the growth and biofilm formation of 13 isolates

\begin{tabular}{|c|c|c|c|c|c|c|c|}
\hline & & \multicolumn{5}{|c|}{ Concentrations of sumach intervals $(\mu \mathrm{l} / \mathrm{ml})$} & \multirow[b]{2}{*}{$\begin{array}{l}1.0 \mu \mathrm{l} / \mathrm{ml} \\
0.5 \mu \mathrm{l} / \mathrm{m}\end{array}$} \\
\hline & & $\begin{array}{c}0.2 \mu \mathrm{l} / \mathrm{ml}- \\
0.1 \mu \mathrm{l} / \mathrm{ml}\end{array}$ & $\begin{array}{c}0.5 \mu \mathrm{l} / \mathrm{ml}- \\
0.1 \mu \mathrm{l} / \mathrm{ml}\end{array}$ & $\begin{array}{l}1.0 \mu \mathrm{l} / \mathrm{ml}- \\
0.1 \mu \mathrm{l} / \mathrm{ml}\end{array}$ & $\begin{array}{c}0.5 \mu \mathrm{l} / \mathrm{ml}- \\
0.2 \mu \mathrm{l} / \mathrm{ml}\end{array}$ & $\begin{array}{l}1.0 \mu \mathrm{l} / \mathrm{ml}- \\
0.2 \mu \mathrm{l} / \mathrm{ml}\end{array}$ & \\
\hline \multirow[t]{3}{*}{$\mathrm{p}$} & $\mathrm{SI}$ & .099 & $.010^{\star}$ & $.001 *$ & .059 & $.001 *$ & $.002^{\star}$ \\
\hline & Slime & .005 * & $.001^{\star}$ & $.001^{\star}$ & $.002^{\star}$ & $.001^{\star}$ & $.001^{\star}$ \\
\hline & Growth & .701 & .152 & $.011^{\star}$ & .600 & $.004^{\star}$ & $.005^{\star}$ \\
\hline
\end{tabular}

directly proportional to the fermented sumach concentration. The fermented sumach, served in four different concentrations, showed the same effect on the biofilm formation and the growth of MSSA and MRSA $(p<0.05)$.

The reduction in $\mathrm{SI}$ and slime, which is a major virulence factor of staphylococcal infections, proved to be statistically significant at four concentrations of sumach. At four concentrations sumach decreased the biofilm formation of 13 strains and reduced the biofilm formation by $48 \%$ at a concentration of $1.0 \mu \mathrm{l} / \mathrm{ml}$ (Table 1). The mean percentage of biofilm of all the strains relative to the control, with a concentration of $0.1,0.2,0.5 \mu \mathrm{l} / \mathrm{ml}$ and $1.0 \mu \mathrm{l} / \mathrm{ml}$ of sumach, was $77.42 \pm 2.67$, $71.18 \pm 2.52,63.25 \pm 2.18(p<0.05)$ and $52.51 \pm 1.98(p<0.05)$, respectively (Table 1$)$. The fermented sumach demonstrated a dose-dependent slime reducing activity (Table 1 and 2). However, $\mathrm{SI}$ indicates that there is no significant decrease in the biofilm between the concentrations of $0.1 \mu \mathrm{l} / \mathrm{ml}$ and $0.2 \mu \mathrm{l} / \mathrm{ml}$ $(p<0.017)$, and between the concentrations of $0.2 \mu \mathrm{l} / \mathrm{ml}$ and $0.5 \mu \mathrm{l} / \mathrm{ml}$ (Table 2). So, the Biofilm inhibition effects of sumach are the same at the concentrations of both $0.1 \mu \mathrm{l} / \mathrm{ml}$ and 0.2 $\mu \mathrm{l} / \mathrm{ml}(\mathrm{p}<0.017)$ and the same at the concentrations of both $0.2 \mu \mathrm{l} / \mathrm{ml}$ and $0.5 \mu \mathrm{l} / \mathrm{ml}$ (Table 2) but are less than the inhibition effect of the concentration of $1.0 \mu \mathrm{l} / \mathrm{ml}$ (Table 1). The most effective concentration is $1.0 \mu \mathrm{l} / \mathrm{ml}$ for biofilm inhibition (Table 1).

\section{Discussion}

Methicillin resistant S.aureus (MRSA) has been shown to be associated with both hospital- and community-acquired infections (1, 2). Büyüktuna et al. (2010) have demonstrated that one of the pathogens of nosocomial infections was Staphylococcus spp. (16.7\%) in an intensive care unit (24). The choice of drugs to be used against MRSA is shrinking day by day, as susceptibility of MRSA to drugs is decreasing by target site alteration, enzyme modification and permeability changes (25).

Studies have been made to decrease adherence of coagulase negative Staphylococcus (CoNS) to catheters by coating them with antiseptics and silver, or by salicylic acid and some other nonsteroidal anti-inflammatory drugs $(26,27)$.

Several studies have been made to manage the microbial biofilm on the biomaterials, including the incorporation of antibiotic and non-antibiotic agents (e.g. usnic acid, epigallocatechin-gallate, ovotransferin, protamine sulfate, surfactin) into biomaterials $(28,29)$. The incorporation of antibiotics on catheters seems to be inappropriate for preventing biofilm formation, since, in contrast to non-antibiotic agents, it can lead to bacterial resistance to antimicrobial agents (28). One study showed that the adhesion and formation of the $S$. epidermidis biofilm on the PCV Nelaton and Thorax catheters had been inhibited by EDTA at low concentrations (between 1-2 mmol/l) (30).

In our data, using $0.1,0.2,0.5$ and $1.0 \mu \mathrm{l} / \mathrm{ml}$ of sumach, thirteen strains lost $17 \%, 22 \%, 28 \%$ and $48 \%$ of their capacity to produce biofilms. Perez Giraldo et al. (24) and Marek Juda et al. (30) studied the effect of EDTA on the formation of biofilm by $S$. epidermidis. According to the data of Perez Giraldo et al. (24) with the highest concentrations $(0.25-8 \mathrm{mg} /$ $\mathrm{mL}$ ), the O.D. of the biofilms diminished and using $1 \mathrm{mg} / \mathrm{mL}$, eight strains caused loss of $75 \%$ of their capacity to produce biofilms. According to Marek Juda et al. (30), EDTA inhibited adhesion and biofilm formation by the $S$. epidermidis isolates on biomaterials at concentrations of $1.0-2.0 \mathrm{mmol} / \mathrm{l}$.

Our results show that sumach decreases growth-independent formation of biofilm, which is a major virulence factor of staphylococcal infections. For this reason, sumach may be an effective alternative for preventing indwelling prosthetic infections by $S$. aureus. This study has demonstrated that the higher dose of sumach, the lower the formation of the biofilms. In the presence of $0.1 \mu \mathrm{l} / \mathrm{ml}$ of sumach or more than this concentration, the results were statistically significant. The sumach which included four different concentrations had the same effect on biofilm formation and growth of MSSA and MRSA.

It would be appropriate to confirm these results by animal experiments. According to this possible confirmation, applica- 
tions of sumach can be researched. Sumach may be administered by direct instillation, orally. However, it may be possible by local application to obtain useful concentrations to prevent the formation of biofilms and adherence of $S$. aureus. This herbal product may be incorporated into indwelling devices for preventing adhesion of $S$. aureus to medical devices. It is difficult to treat an infected device, by this way this can be prevented by sumach. Indwelling device associated infections, even MRSA infections, may be prevented without using antibiotics or other chemicals causing resistance to bacteria. If these results would be confirmed by animal and clinical experiments, freeze dried tablets which contain ingredients of sumach may also be produced by drug companies.

In conclusion, our results suggest that sumach may prevent the formation of biofilms and adherence of $S$. aureus. When incurable indwelling device associated infections arise due to $S$. aureus, sumach can be an alternative treatment option if this could be confirmed by animal and clinical experiments. We consider that it would be appropriate to carry out animal and clinical studies to confirm this.

\section{Acknowledgements}

I am grateful to Assist. Prof. Dr. Aysu Kıyan for the statistical studies. I also warmly thank Assist. Prof. Dr. Alper Karakaş, for allowing me to use the microplate reader in his laboratory.

\section{Conflict of Interest}

No conflict of interest was declared by the authors.

\section{References}

1. Harbarth S, Masuet-Aumatell C, Schrenzel J, Francois P, Akakpo $C$, Renzi $G$, et al. Evaluation of rapid screening and pre-emptive contact isolation for detecting and controlling methicillin-resistant Staphylococcus aureus in critical care: an interventional cohort study. Critical Care 2006;10:R25. [CrossRef]

2. Kluytmans J. Control of meticillin-resistant Staphylococcus aureus (MRSA) and the value of rapid tests. Journal of Hospital Infection 2007; 65 Suppl 2:100-4. [CrossRef]

3. Livermore DM. Antibiotic resistance in staphylococci. Int J Antimicrob Agents 2000;16 Suppl 1:S3-10. [CrossRef]

4. Vuong C, Otto M. Staphylococcus epidermidis infections. Microbes Infect 2002;4:481-9. [CrossRef]

5. von Eiff C, Heilmann C, Herrmann M, Peters G. Basic aspects of the pathogenesis of staphylococcal polymer-associated infections. Infection 1999;27 Suppl 1:S7-10. [CrossRef]

6. Darouiche, RO. Treatment of infections associated with surgical implants. N Engl J Med 2004;350:1422-9. [CrossRef]

7. Costerton JW, Montanaro L, Arciola CR. Biofilm in implant infections: its production and regulation. Int J Artif Organs 2005;28:1062-8.

8. Dunne WM, Jr, Mason EO Jr, Kaplan SL. Diffusion of rifampin and vancomycin through a Staphylococcus epidermidis biofilm. Antimicrob Agents Chemother 1993;37:2522-6.

9. Fluit AC, Wielders CLC, Verhoef J, Schmitz FJ. Epidemiology and susceptibility of 3,051 Staphylococcus aureus isolates from 25 university hospitals participating in the European SENTRY Study. J Clin Microbiol 2001;39:3727-32. [CrossRef]

10. Adwan K, Abu-Hasan N, Adwan G, Jarrar N, Abu-Shanab B, Abu-Zant A. Nosocomial infection caused by methicillin-resistant Staphylococcus aureus in Palestine. Microb Drug Resist 2005;11:75-7. [CrossRef]
11. Fridkin SK, Hageman JC, Morrison M, Sanza LT, Como-Sabetti $\mathrm{K}$, Jernigan JA, et al. Methicillin-resistant Staphylococcus aureus disease in three communities. N Engl J Med 2005;352:1436-44. [CrossRef]

12. Schito GC. The importance of the development of antibiotic resistance in Staphylococcus aureus. Clin Microbiol Infect 2006;12 Suppl 1:3-8. [CrossRef]

13. Blatnik J, Lesnicar G. Propagation of methicillin-resistant Staphylococcus aureus due to the overloading of medical nurses in intensive care units. J Hosp Infect 2006;63:162-6. [CrossRef]

14. Saxena G, McCutcheon AR, Farmer S, Towers GHN, Hancock REW. Antimicrobial constituents of Rhus glabra. J Ethnopharmacology 1994;42:95-9. [CrossRef]

15. McCutcheon AR, Ellis SM, Hancock RE, Towers GH. Antifungal screening of medicinal plants of British Columbian native peoples. J Ethnopharmacology 1994;44:157-69. [CrossRef]

16. Chung KT, Wong TY, Wei Cl, Huang YW, Lin Y. Tannins and human health: a review. Crit Rev Food Sci Nutr 1998;38:421-64. [CrossRef]

17. Nasar-Abbas SM, Halkman AK. Antimicrobial effect of water extract of sumac (Rhus coriaria L.) on the growth of some food borne bacteria including pathogens. Int J Food Microbiol 2004;97:63-9. [CrossRef]

18. Booth IR, Kroll RG. The preservation of foods by low $p H, I n G$. W. Gould (ed.). Mechanisms of action of food preservation procedures. Elsevier Science Publishers, New York, N.Y; 1989. p. 119-60.

19. Stradford M, Anslow PA. Evidence that sorbic acid does not inhibit yeast as a classic 'weak acid preservative'. Lett Appl Microbiol 1998;27:203-6.

20. Brul S, Coote P. Preservative agents in foods. Mode of action and microbial resistance mechanism. Int J Food Microbiol 1999;50: 1-17. [CrossRef]

21. Freeman DJ, Falkiner FR, Keane CT. New method for detecting slime production by coagulase negative staphylococci. J Clin Pathol 1989;42:872-4. [CrossRef]

22. Christensen GD, Simpson WA, Younger JJ, Baddour LM, Barrett FF, Melton DM, et al. Adherence of coagulase-negative staphylococci to plastic tissue culture plates: a quantitative model for the adherence of staphylococci to medical devices. J Clin Microbiol 1985;22:996-1006.

23. Pérez-Giraldo $C$, Rodríguez-Benito A, Morán FJ, Hurtado C, Blanco MT, Gómez-García AC. Influence of $\mathrm{N}$-acetylcysteine on the formation of biofilm by Staphylococcus epidermidis. J Antimicrob Chemother 1997;39:643-6. [CrossRef]

24. Büyüktuna $S A$, Turhan Ö, Cengiz $M$, Ramazanoğlu A, Yalçın AN. Nosocomial Infections and Agents Determined by Consultations in Intensive Care Unit. Balkan Med J 2010;27:150-5.

25. Brumfitt W, Hamiltton-Miller J. Methicillin resistant Staphylococcus aureus. N Engl J Med 1989;320:1188-96. [CrossRef]

26. Flowers RH 3rd, Schwenzer KJ, Kopel RF, Fisch MJ, Tucker SI, Farr BM. Efficacy of an attachable subcutaneous cuff for the prevention of intravascular catheter-related infection. A randomized controlled trial. JAMA 1989;261:878-83. [CrossRef]

27. Farber BF, Wolff AG. The use of nonsteroidal antiinflammatory drugs to prevent adherence of Staphylococcus epidermidis to medical polymers. J Infect Dis 1992;166:861-5. [CrossRef]

28. Percival SL, Kite P, Eastwood K, Murga R, Carr J, Arduino MJ, et al. Tetrasodium EDTA as a novel central venous catheter lock solution against biofilm. Infect Control Hosp Epidemiol 2005;26:515-7. [CrossRef]

29. Yakandawala N, Gawande PV, LoVetri K, Madhyastha S. Effect of ovotransferrin, protamine sulfate and EDTA combination on biofilm formation by catheter-associated bacteria. J Appl Microbiol 2007;102:722-7. [CrossRef]

30. Juda M, Paprota K, Jałoza D, Malm A, Rybojad P, Gozdziuk K. EDTA as a potential agent preventing formation of Staphylococcus epidermidis biofilm on polichloride vinyl biomaterials. Ann Agric Environ Med 2008;15:237-41. 